\title{
ASSESSMENT AND EVALUATION IN OPEN EDUCATION SYSTEM: STUDENTS' OPINIONS ABOUT OPEN-ENDED QUESTION (OEQ) PRACTICE
}

\author{
Dr. Nejdet KARADAG \\ ORCID: 0000-0002-9826-1297 \\ Open Education Faculty \\ Anadolu University \\ Eskisehir, TURKEY \\ Dr. Belgin BOZ YUKSEKDAG \\ ORCID: 000-0003-2862-3544 \\ Open Education Faculty \\ Anadolu University \\ Eskisehir, TURKEY \\ Dr. Murat AKYILDIZ \\ ORCID: 000-0001-5069-0132 \\ Open Education Facult \\ Anadolu University \\ Eskisehir, TURKEY \\ Ali Ihsan IBILEME \\ ORCID: 0000-0002-4705-3973 \\ Computer Research Center \\ Anadolu University \\ Eskisehir, TURKEY
}

Received: 27/08/2020 Accepted: 27/09/2020

\begin{abstract}
The aim of this study is to determine students' opinions about open-ended question exam practice during 2018-2019 academic year for the following programs of Anadolu University Open Education System: Economy, Hospitality Management, Philosophy, History, Sociology, and Turkish Language and Literature. The study was designed as a quantitative study that describes an existing situation. The measurement tool developed to achieve that purpose includes 5 Likert type questions, 8 closed-ended question -3 of which are yes-no questions-, and 2 open-ended questions. The data were collected between February $14^{\text {th }} 2020$ and February $16^{\text {th }} 2020$ and 3236 students responded to the tool in total. Percentage-frequency tables and graphs were used for the analysis of the data collected. Since each question in the tool measured a different and independent dimension of the research, the tool was not taken as a scale, so each question was analyzed separately. The data were recoded for certain questions and chi-square analysis was done by using "age", "gender" and "the program they attend" variables.

The results of the study showed that majority of the participants find open-ended questions more difficult than multiple-choice questions and have negative opinions about open-ended questions in terms of measuring subject matter competency and fair assessment.
\end{abstract}

Keywords: Open Education, open ended questions, measurement, evaluation. 


\section{INTRODUCTION}

A teaching program consists of the following main components: objectives, scope, learning activities, and measurement and evaluation. Objectives refer to the skills to be developed during the program; scope is the content to be covered to achieve the predetermined objectives; and learning activities are the activities prepared in parallel with the objectives and content. Assesment and evaluation is about testing whether students have achieved predetermined objectives and target behaviors or not (Yasar, 2014).

"Assesment and evaluation" is the basic element of any educational practice and search for quality in education. Simonson, Smaldino, Albright, Zwacek (2012) stated that the data obtained through the evaluation of learning performance can be used to facilitate learning, to evaluate and improve the program, to place students in the program, to make funding priority decisions and to report long term tendencies to governments and institutions.

Assessment of students in open and distance education systems is a problematic process because students are often from different age groups and occupations, have different learning materials, different purposes to be enrolled in programs and different criteria for success (Thorpe, 1988). In addition, there are certain limitations when compared to traditional education environments because teachers and students are in different physical environments (Puspitasari, 2010). Therefore, teachers have limited options for measuring students' performances in open and distance education systems (McIsaac and Gunawardena, 1996).

Due to above mentioned reasons, some measurement and evaluation activities are based on study materials designed according to self-learning principles, and timed and invigilated exams are used while determining success level of students (Karadag, 2005). Although today's technological advancements provide new alternatives for teachers, it is still not possible to achieve complete exam security and secure identity check in new learning environments.

As the main measurement tools, Anadolu University Open Education system uses multiple choice tests, which are also known as objective tests, in addition to homework and portfolios. The research showed that students also prefer alternative assessment tools such as true/false tests, matching tests, homework/project, and graduation dissertation (Karadag, 2014). Using some of these measurement tools will be possible when online exam system is implemented, which is also another preference stated by students. In open-ended questions, students can structure their own answers, explain the reasons for their answers and express their opinions freely and uniquely (Gronlund, 1998).

Various measurement tools used in formal education should also be used in open and distance learning applications, and Open-ended questions should be used as an alternative to multiple choice questions (Karadeniz, 2016).

Open-ended questions are more advantageous than multiple choice questions in that they minimize measurement errors by eliminating chance success, and they are suitable for partial grading and easier to prepare (Tan and Erdogan, 2004; Bahar, Nartgun, Durmus and Bicak, 2010; Ilhan, 2016)

However, open-ended questions have some disadvantages such as time-consuming administration and scoring, difficulty of ensuring content validity, fewer number of questions due to time constraints and, most importantly, lack of objective scoring (Ozcelik, 2011; Dogan, 2013; Ilhan, 2016).

Open-ended questions refer to classical and written question types that cannot simply be answered as "yes/ no". The emotions and opinions of those who answer these questions are determined through certain analysis. Open-ended questions are often asked as the last question of classical exams. Open-ended question practice in Anadolu University Open Education system started in 2017-2018 academic year. The tests consist of 16 multiple-choice questions (5 points each), two short answer questions (5 points each) and one long answer question (10 points). These questions are graded through online Open-ended Question Evaluation System in Anadolu University Open Education System. In this study, it is aimed to detect students' opinions about open-ended question exam practice during 2018-2019 academic year for the following programs of Anadolu University Open Education System: Economy, Hospitality Management, Philosophy, History, Sociology, and Turkish Language and Literature. The study was designed as a quantitative study that describes an existing situation. The results of this study will contribute to the development of open-ended question applications. 


\section{ANADOLU UNIVERSITY OPEN EDUCATION SYSTEM OPEN-ENDED QUESTION EVALUATION SYSTEM}

Six programs in Anadolu University Open Education System use open-ended questions in the midterms at undergraduate level. Computer Research and Application Center (CRAC) Web Group has established a unit to evaluate open-ended questions. Open-ended question system in Anadolu University Open Education Ssytem consists of two phases: administration and evaluation. In the first phase, long and short answer questions to be asked in the exams are collected from the course coordinators by Test Research Unit, These questions and other questions in the question bank are used as exam questions. Selected questions are placed in the exam booklet for each course after the multiple-choice questions. Three open-ended questions - two short answer questions and one long answer question - are asked in each exam. (CRAC) Test Software Team prepare an extra form for these open-ended questions in addition to the regular optic form for multiple questions. There are empty spaces on this special form for fill-in-the-blanks or short answer questions as well as the long answer question. Students mark their answers in the optic form for multiple-choice questions while they use the other form for open-ended questions. After the administration of the exam, the optic forms are scanned and digitalized by CRAC. Later, the scanned forms are sent to the Open-ended Question Evaluation System. The following procedure is followed prior to the evaluation process:

- Preparation of open-ended questions

- Printing optic forms

- Administration of the exam

- Scanning the optic forms

Scanned forms are assigned to graders, and each form is graded by two different graders according to the rubric and grades are announced when multiple choice questions are scored and combined with those taken from open-ended ones."

\section{METHODOLOGY}

The study examines students' opinions regarding open-ended question practice in the exams of Anadolu University Open Education System. It was designed as a quantitative study aiming to determine students' opinions regarding open-ended question practice in the exams.

\section{Participants}

The participants of the study are 3.236 students out of 14.565 students who took open-ended questions in the midterm exams in 2018-2019 at Anadolu University Open Education System. Table 1 displays demoGraph information about the participant students such as the program they attend, age and gender.

Tablo 1. The Distribution of Participants according to the Programs They Attend, Age and Gender

\begin{tabular}{lcccccccc}
\hline Program & $\mathrm{N}$ & $\%$ & Age & $\mathrm{N}$ & $\%$ & Gender & $\mathrm{N}$ & $\%$ \\
\hline Sociology & 1320 & 40.8 & $17-22$ & 71 & 2.2 & Female & 1671 & 51.6 \\
Economy & 894 & 27.6 & $23-28$ & 813 & 25.1 & Male & 1565 & 48.4 \\
Hospitality Management & 322 & 9.9 & $29-34$ & 880 & 27.2 & & & \\
Turkish Language and Literature & 272 & 8.4 & $35-40$ & 645 & 19.9 & & \\
History & 261 & 8.1 & $41-46$ & 449 & 13.9 & & \\
Philosophy & 167 & 5.2 & $47+$ & 378 & 11.7 & & \\
\hline
\end{tabular}

Table 1 shows that the percentage of the participants attending the Sociology program is the highest (\%40.8) and the Philosophy program the lowest (\%5.2). This result is consistent with the number of students taking the open-ended question exam in terms of the programs they attend. As for the age ranges of the participants, 29-34 age range has the highest number of participants (\%27.2) and 17-22 age range the lowest (\%2.2). 
This finding also reflects the student profile in Anadolu University Open Education System. Finally, the data regarding the gender distribution of the participants shows that $\% 52.6$ of the participants are female and $\% 48.4$ male. This distribution ratio is quite similar to that of 14565 students who took open-ended question exam although the study did not use any sampling method while determining the participants.

\section{Data Collection Tool}

The data were collected through a measurement tool prepared via the Google Form. The tool includes 5 Likert type questions, 8 closed-ended questions - three of which are yes-no questions- and 2 open-ended questions. One of these open-ended questions allows the participants to write about why they did not reply open-ended questions, and the second open-ended question aims to collect data regarding their opinions about open-ended question practice. Although each item used separately and scale scores haven't used as sum scores, scale's Cronbach Alfa internal consistency reliability was found as 0.89 . This means that the scale is highly reliable. The measurement tool was examined by three experts forcontent validity.

\section{Data Collection Procedures}

14565 students who took open-ended question exam were sent the link of and the information text about the measurement tool via e-mail and SMS. The information text involved the potential advantages of the study to improve the system and stated that the participation in the study is voluntary. The replies were collected between February $14^{\text {th }}$ and February $16^{\text {th }} 2020$.

\section{Data Analysis}

Percentage-frequency and graphs of the data collected were used for analysis purposes. Percentage-frequency graphs were prepared and interpreted for each item in the measurement tool. Since each question in the tool measured a different and independent dimension of the research, the tool was not taken as a scale, so each question was analyzed separately. The data were recoded for certain questions and chi-square analysis was done by using "age", "gender" and "the program they attend" variables.

\section{FINDINGS}

This section presents and discusses the findings obtained from 3.236 participants who answered the questions in the measurement tool.

\section{The Opinions regarding Whether "Open-ended Questions Measure Important Knowledge in the Subject Matter Better or Not"}

$\% 43.45$ of the participants provided "Totally disagree" answer for the question aiming to determine students' opinions about to what extent open-ended questions measure their subject matter knowledge. $\% 21.9$ reported that they do not agree with this statement. The percentage of those who marked "Strongly Agree" is \% 8.25 , and "Agree" option was chosen by $\% 14.96$ of the participants. Graph 1 shows that majority of the participants do not believe that open-ended questions measure important knowledge in subject matter better. 


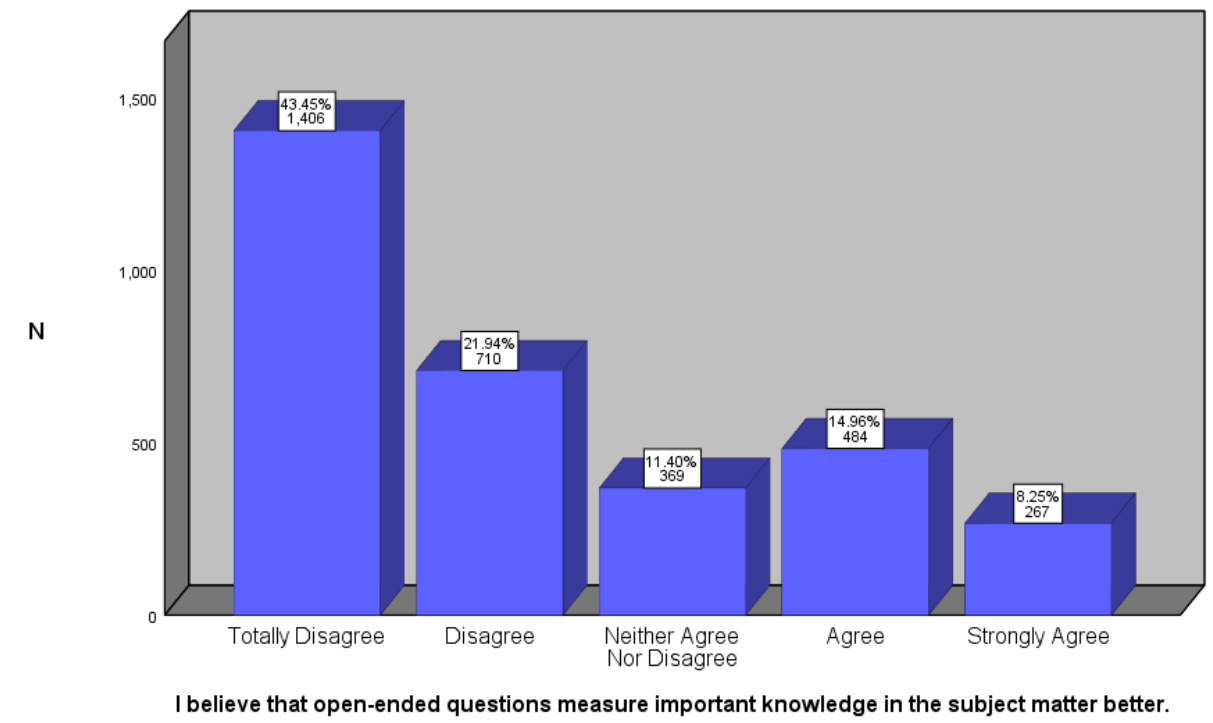

Graph 1. The level of agreement about whether open-ended questions measure important knowledge in the subject matter better or not

\section{The Opinions regarding Whether "Open-ended Questions are Fairly Graded or Not"}

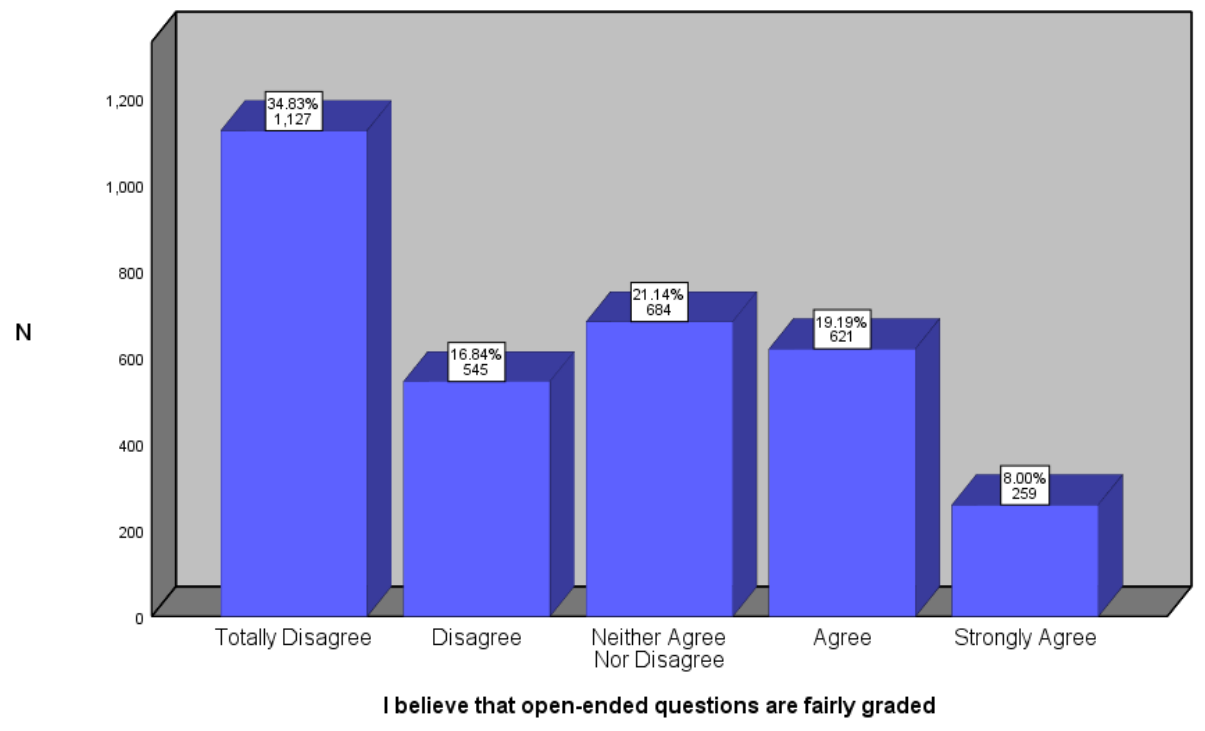

Graph 2. The opinions regarding whether "open-ended questions' are fairly graded or not

$\% 34.83$ of the participants do not agree at all with the statement "I believe that open-ended questions are fairly graded" and \%16.84 do not agree with it. "Strongly Agree" option was marked by \%8 of the participants and "Agree" option by \%19.9. It is clear that more than half of the participants think that evaluation of open ended questions is not fairly done while \%21.14 are undecided about this statement. 


\section{The Opinions regarding Whether "The Points Obtained from Open-ended Questions Reflect Students' Knowledge Level or Not"}

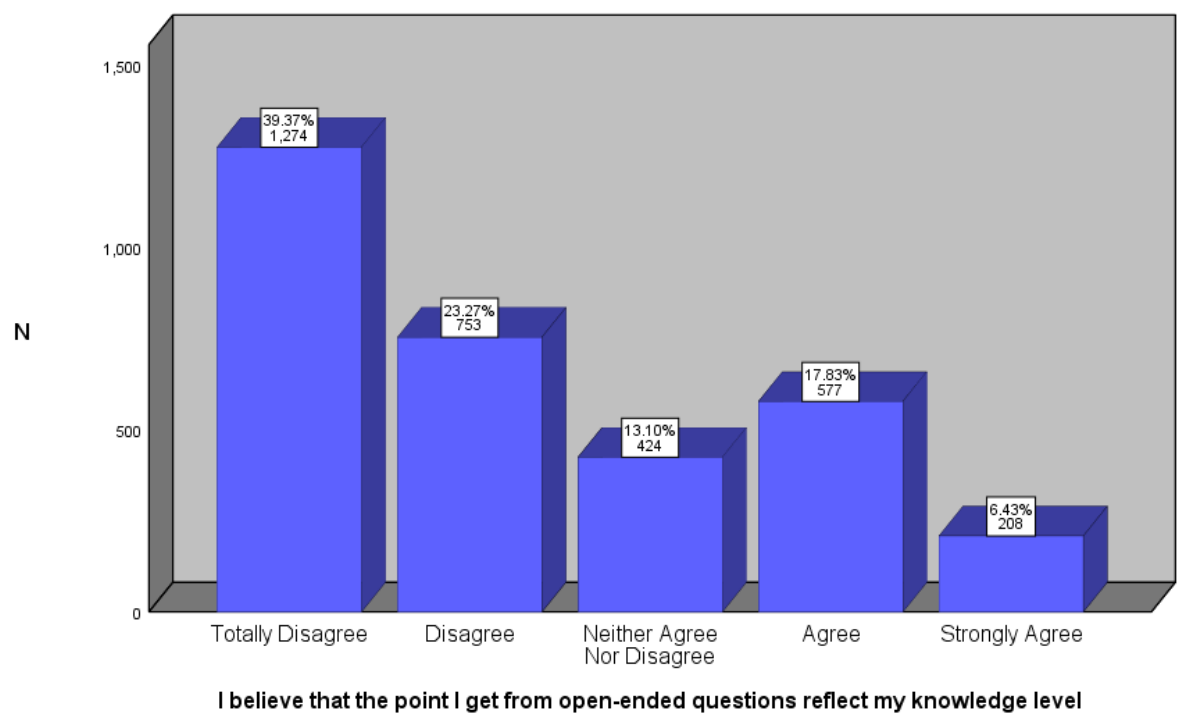

Graph 3. The Opinions regarding Whether the Points Obtained from Open-ended Questions Reflect Students' Knowledge Level or not

As for the statement "I believe that the point I get from open-ended questions reflects my knowledge level", $\% 39.37$ of the participants marked "Totally disagree" option and \%23.27 "Disagree" option. The total percentage of those who chose "Agree" and "I Strongly agree" option is \%24.26. Graph 3 shows that a great majority of the participants do not believe that the points they get from open-ended questions reflect their knowledge level.

\section{The Opinions regarding Whether "Open-ended Questions were Easy or Not"}

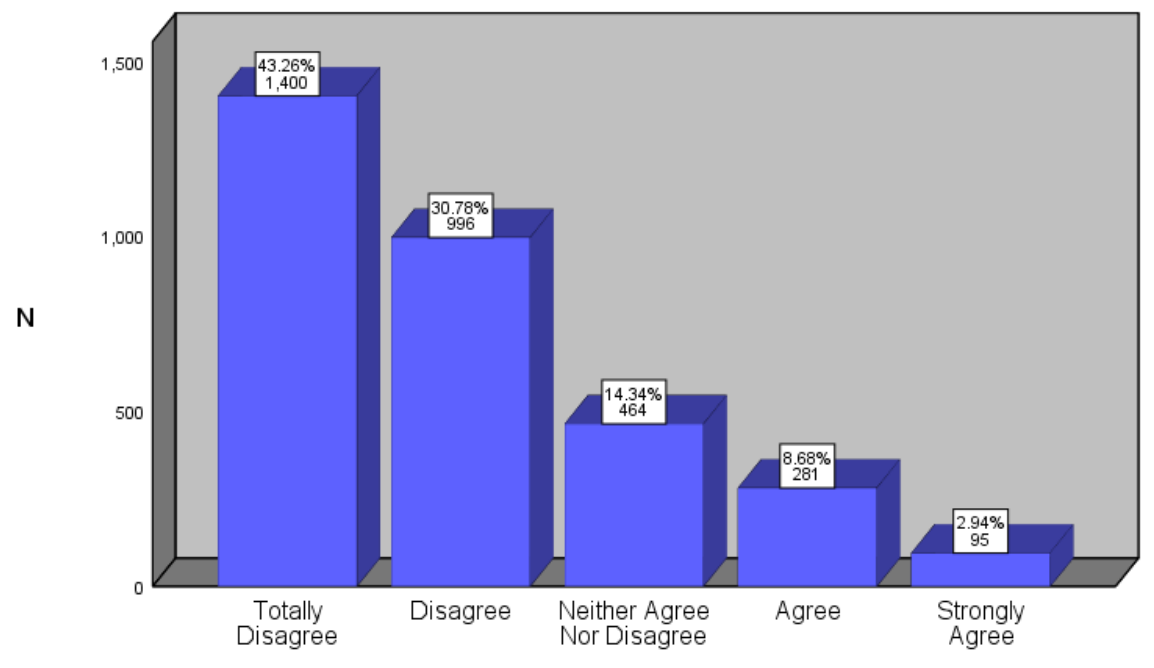

Open-ended questions were much easier than multiple-choice questions

Graph 4. The Opinions regarding Whether Open-ended Questions were Easy or not

According to Graph 4, majority of the participants found open-ended questions more difficult than multiplechoice questions. The percentage of participants who replied the statement above as "Totally Disagree" is \%43.26 and "Disagree" \%30.78, which makes \%74.04 in total. However, \%2.94 of the participants "Strongly Agree" with the statement and \%8.68 agreed, which makes \%10.62 in total. 


\section{The Opinions regarding Whether "Long Answer Open-ended Questions Measure Subject Matter Competence"}



Graph 5. The Opinions regarding whether Long Answer Open-ended Questions Measure Subject Matter Competence

$\% 41.38$ of the participants totally disagree with the statement "I find long answer questions useful in terms of measuring subject matter competence." and \%25.15 disagree with it. In total, \%66.53 of the participants express a sort of disagreement for the statement, while \%21.94 of the participants agree with the statement (\%15.98 - Agree- and \%5.96 - Strongly Agree). These percentages suggest that majority of the participants think long answer open-ended questions do not measure subject matter competencies.

\section{The Opinions regarding the Statement "I would Prefer that the Exam should Include Only Open-Ended Questions"}

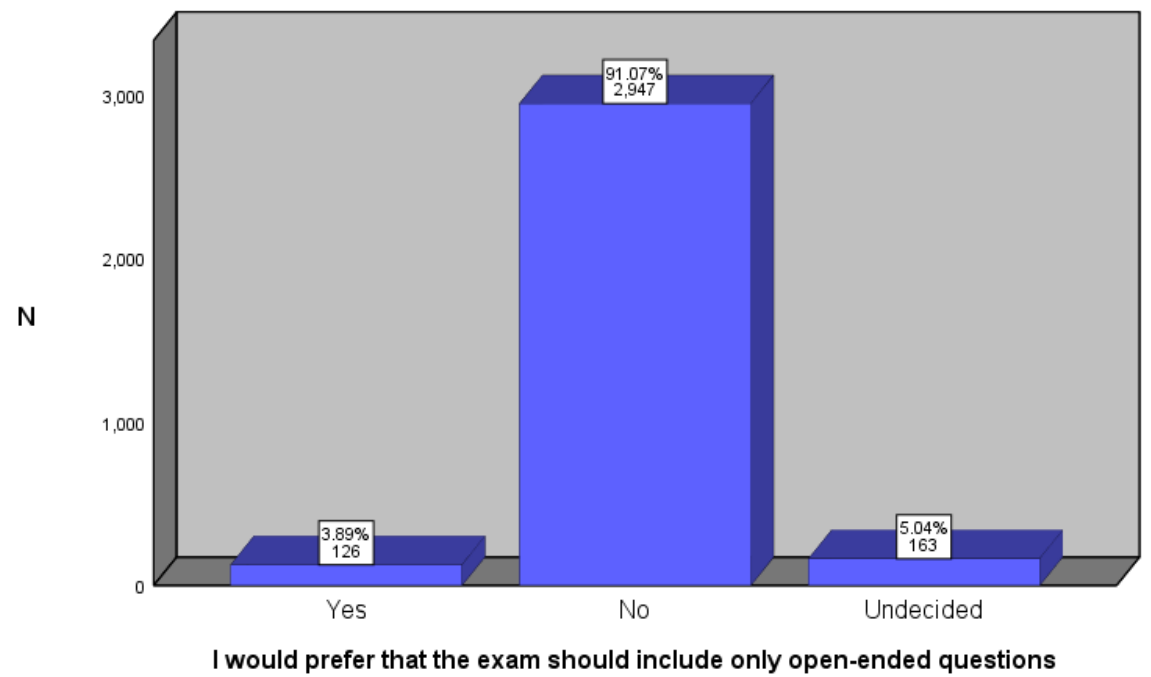

Graph 6. The Opinions regarding the Statement "I would prefer that the exam should include only openended questions"

$\% 91.07$ of the participants disagree with the idea that the exam should include only open-ended questions while only \%3.89 replied to the statement above by marking the option "YES". 


\section{The Opinions regarding the Time Allocated to Answer Open-ended Questions}

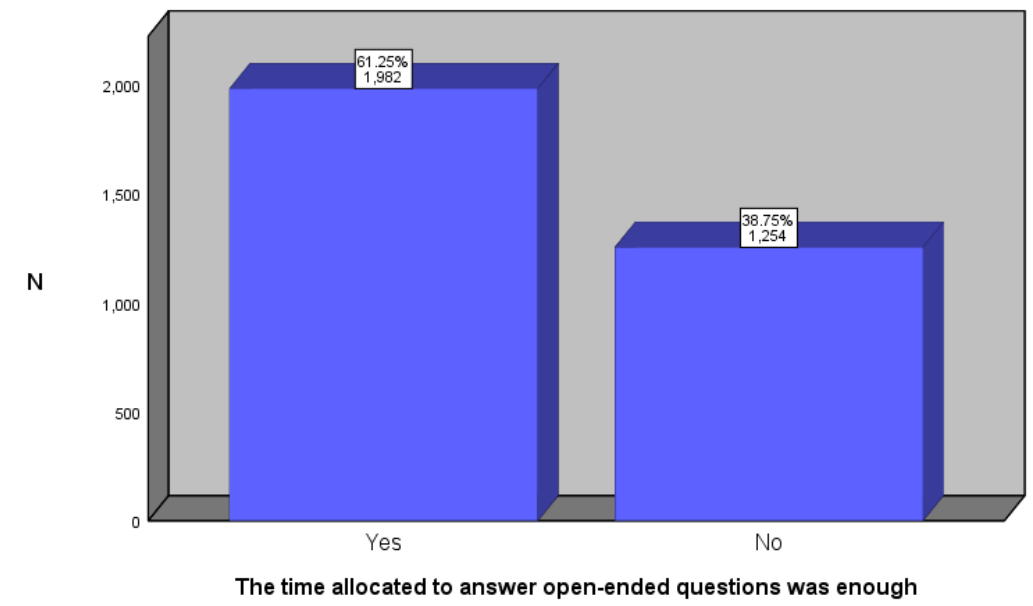

Graph 7. The Opinions regarding the Time Allocated to Answer Open-ended Questions

$\% 61.25$ of the participants think that the time allocated to answer open-ended questions is enough while $\% 38.85$ disagreed with this statement.

\section{The Opinions regarding the Reasons for Leaving Open-ended Questions Blank}

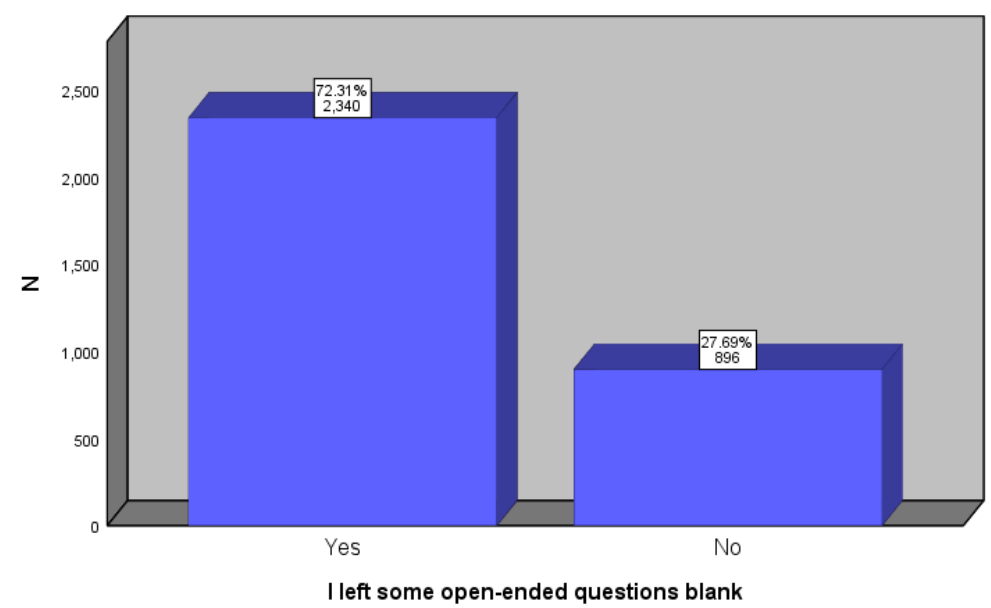

Graph 8. The Percentage of those Leaving Open-ended Questions Blank

$\% 72.31$ of the participants reported that they left some open-ended question blank while $\% 27.69$ stated that they answered these questions.

In order to examine the participants' opinions according to demoGraph variables, "Strongly agree" and "Agree" Likert type options were recoded as "Agree"; and "Disagree" and "Totally disagree" options as "Disagree". "Undecided" option was not included in the analysis. By doing so, all the data obtained from Likert type questions were analyzed as if they had only two options, which made chi-square statistics possible between demoGraph variables and recoded variables.

Table 2 below shows chi-square test results, which was done to examine the replies provided by the participants according to gender variable. 
Table 2. Chi-Square Table Displaying Agreement on Statements according to Gender

\begin{tabular}{lllll}
\hline & & Male & Female & Total \\
\hline \multirow{2}{*}{ OEQ (Open-Ended Questions) measure better } & Disagree & $82.7 \%_{\mathrm{a}}$ & $80.0 \%_{\mathrm{a}}$ & $81.40 \%$ \\
& Agree & $17.3 \% \mathrm{a}_{\mathrm{a}}$ & $20.0 \% \mathrm{a}_{\mathrm{a}}$ & $18.60 \%$ \\
\hline
\end{tabular}

$X^{2}=3.184 ; d f=1 ; p>0.05$

\begin{tabular}{lllll}
\hline & & Male & Female & Total \\
\hline \multirow{2}{*}{ OEQ are more fair } & Disagree & $75.1 \%_{\mathrm{a}}$ & $80.0 \%_{\mathrm{a}}$ & $81.40 \%$ \\
& Agree & $24.9 \%_{\mathrm{a}}$ & $20.0 \%_{\mathrm{a}}$ & $18.60 \%$ \\
\hline
\end{tabular}

$X^{2}=5.99 ; d f=1 ; p<0.05$

\begin{tabular}{lllll}
\hline & & Male & Female & Total \\
\hline \multirow{2}{*}{ OEQ reflect my knowledge level } & Disagree & $79.1 \%_{\mathrm{a}}$ & $70.6 \%_{\mathrm{b}}$ & $72.90 \%$ \\
& Agree & $20.9 \%_{\mathrm{a}}$ & $29.4 \%_{\mathrm{b}}$ & $27.10 \%$ \\
\hline
\end{tabular}

$X^{2}=2.519 ; d f=1 ; p>0.05$

\begin{tabular}{lllll}
\hline & & Male & Female & Total \\
\hline \multirow{2}{*}{ OEQ were easier } & Disagree & $91.6 \% a$ & $76.5 \%{ }_{a}$ & $77.80 \%$ \\
& Agree & $8.4 \% a$ & $23.5 \%$ & $22.20 \%$ \\
\hline
\end{tabular}

$X^{2}=13.693 ; d f=1 ; p<0.05$

\begin{tabular}{lllll}
\hline & & Male & Female & Total \\
\hline \multirow{2}{*}{ EOQ are useful } & Disagree & $82.2 \%{ }_{a}$ & $87.3 \% \mathrm{~b}$ & $89.50 \%$ \\
& Agree & $17.8 \%{ }_{\mathrm{a}}$ & $12.7 \% \mathrm{~b}$ & $10.50 \%$ \\
\hline
\end{tabular}

$X^{2}=13.693 ; d f=1 ; p<0.05$

"Subscripted letters" under the percentages show the gender group that shows significant difference at 05 level of significance.

The data in Table 2 reveal that the agreement levels of the participants with "more fair" "easier" and "more useful" statements are significantly different according to gender variable $((\mathrm{X} 2=5.99, \mathrm{df}=1, \mathrm{p}<0.05$; $\mathrm{X} 2=13.693, \mathrm{df}=1, \mathrm{p}<0.05 ; \mathrm{X} 2=13.693, \mathrm{df}=1, \mathrm{p}<0.05)$ respectively). Accordingly, males reported higher level of disagreement for "open-ended questions are fairly graded" statement although majority of both male and female participants disagreed with it. Similarly, a high percentage of both males and females did not agree with the statement "open-ended questions were easier", and males disagreed less. In addition, high percentage of the participants disagreed with the usefulness of open-ended questions in reflecting knowledge level, and males stated relatively lower level of disagreement with this idea. However, the agreement level of the participants with the statement "open-ended questions measure subject matter better" is not significantly different according to gender variable and males displayed lower level of agreement than females. In other words, the opinions of males and females regarding this statement do not differ significantly. 
Table 3. Chi-Square Table showing how levels of Agreement with the Statements change according to the Age Variable

\begin{tabular}{|c|c|c|c|c|c|c|c|c|}
\hline & & $17-22$ & $23-28$ & $29-34$ & $35-40$ & $41-46$ & $\begin{array}{l}47 \text { and } \\
\text { above }\end{array}$ & Total \\
\hline \multirow{2}{*}{$\begin{array}{l}\text { OEQ (Open-Ended } \\
\text { Questions) measure better }\end{array}$} & Disagree & $82.8 \%_{a, b, c}$ & $86.8 \%_{c}$ & $84.4 \%_{b, c}$ & $80.0 \%_{a, b}$ & $74.2 \%_{a}$ & $71.5 \%{ }_{a}$ & $81.40 \%$ \\
\hline & Agree & $17.2 \%_{a, b, c}$ & $13.2 \%_{c}$ & $15.6 \%_{b, c}$ & $20.0 \%_{a, b}$ & $25.8 \% \mathrm{a}_{\mathrm{a}}$ & $28.5 \%$ & $18.60 \%$ \\
\hline
\end{tabular}

$X^{2}=47.857 ; d f=5 ; p<0.05$

\begin{tabular}{|c|c|c|c|c|c|c|c|c|}
\hline & & $17-22$ & $23-28$ & $29-34$ & $35-40$ & $41-46$ & $\begin{array}{l}47 \text { and } \\
\text { above }\end{array}$ & Total \\
\hline \multirow{2}{*}{ OEQ are more fair } & Disagree & $75.5 \%_{a, b, c}$ & $79.7 \%_{c}$ & $78.7 \%_{c}$ & $70.3 \%_{b}$ & $63.8 \%_{a, b}$ & $59.2 \%{ }_{a}$ & $72.90 \%$ \\
\hline & Agree & $24.5 \%_{a, b, c}$ & $20.3 \%_{c}$ & $21.3 \%_{c}$ & $29.7 \%_{b}$ & $36.2 \%_{a, b}$ & $40.8 \%{ }_{a}$ & $27.10 \%$ \\
\hline
\end{tabular}

$X^{2}=64.009 ; d f=5 ; p<0.05$

\begin{tabular}{lllllllll}
\hline & $17-22$ & $23-28$ & $29-34$ & $35-40$ & $41-46$ & $\begin{array}{c}47 \text { and } \\
\text { above }\end{array}$ & Total \\
\hline \multirow{2}{*}{$\begin{array}{l}\text { OEQ reflect my knowledge } \\
\text { level }\end{array}$} & $\begin{array}{l}\text { Disagree } \\
\text { Agree }\end{array}$ & $78.2 \%_{\mathrm{a}, \mathrm{b}, \mathrm{c}, \mathrm{d}}$ & $84.4 \%_{\mathrm{d}}$ & $81.5 \%_{\mathrm{c}, \mathrm{d}}$ & $75.9 \%_{\mathrm{b}, \mathrm{c}}$ & $71.2 \%_{\mathrm{a}, \mathrm{b}}$ & $65.3 \%_{\mathrm{a}}$ & $77.80 \%$ \\
\hline
\end{tabular}

$X^{2}=58.803 ; d f=5 ; p<0.05$

\begin{tabular}{lllllllll}
\hline & & $17-22$ & $23-28$ & $29-34$ & $35-40$ & $41-46$ & $\begin{array}{c}47 \text { and } \\
\text { above }\end{array}$ & Total \\
\hline \multirow{2}{*}{ OEQ were easier } & Disagree & $81.7 \%_{a}$ & $91.2 \%_{a}$ & $90.5 \%_{a}$ & $90.6 \%_{a}$ & $86.4 \%_{a}$ & $86.6 \%_{a}$ & $89.50 \%$ \\
& Agree & $18.3 \%_{a}$ & $8.8 \%_{a}$ & $9.5 \%_{a}$ & $9.4 \%_{a}$ & $13.6 \%_{a}$ & $13.4 \%_{a}$ & $10.50 \%$ \\
\hline
\end{tabular}

$X^{2}=13.908 ; d f=5 ; p>0.05$

\begin{tabular}{|c|c|c|c|c|c|c|c|c|}
\hline & & $17-22$ & $23-28$ & $29-34$ & $35-40$ & $41-46$ & $\begin{array}{l}47 \text { and } \\
\text { above }\end{array}$ & Total \\
\hline \multirow{2}{*}{ EOQ are useful } & Disagree & $77.8 \%_{a, b, c}$ & $86.8 \%_{c}$ & $82.7 \%_{c}$ & $81.7 \%_{b, c}$ & $74.9 \%_{a, b}$ & $67.2 \%$ & $80.60 \%$ \\
\hline & Agree & $22.2 \%_{a, b, c}$ & $13.2 \%_{c}$ & $17.3 \%_{c}$ & $18.3 \%_{b, c}$ & $25.1 \%_{a, b}$ & $32.8 \%{ }_{a}$ & $19.40 \%$ \\
\hline
\end{tabular}

$X^{2}=61.826 ; d f=5 ; p<0.05$

"Subscripted letters" under the percentages show the gender group that shows significant difference at 05 level of significance.

Table 3 shows that there is a significant difference for all the statements about the open-ended question in the measurement tool for all age ranges, and disagreement levels are quite high. Disagreement for the statements "open-ended questions measure subject matter knowledge better", "open-ended questions are fairly graded" and "open-ended questions are useful in terms of measuring subject matter competence" is higher for 17-34 age group than 35 and above age group. In addition, 23-24 age group tended to disagree more than other age groups for the statement "Open-ended questions reflect my knowledge level." 
Table 4. Chi-Square Table showing how levels of Agreement with the Statements change according to "the program they attend" variable

\begin{tabular}{lcccccccc}
\hline & & Philosophy & $\begin{array}{c}\text { Turkish Language } \\
\text { and Literature }\end{array}$ & Economy & History & $\begin{array}{c}\text { Hospitality } \\
\text { Management }\end{array}$ & Sociology & Total \\
\hline $\begin{array}{l}\text { OEQ (Open- } \\
\begin{array}{l}\text { Ended Questions) } \\
\text { measure better }\end{array}\end{array}$ & Agree & $33.3 \%_{\mathrm{a}}$ & $36.8 \%_{\mathrm{a}}$ & $11.9 \%_{\mathrm{b}}$ & $26.0 \%_{\mathrm{a}, \mathrm{c}}$ & $15.5 \%_{\mathrm{b}, \mathrm{c}}$ & $17.9 \%_{\mathrm{c}}$ & $18.60 \%$ \\
\hline
\end{tabular}

$X^{2}=89.187 ; d f=5 ; p<0.05$

\begin{tabular}{|c|c|c|c|c|c|c|c|c|}
\hline & & Philosophy & $\begin{array}{l}\text { Turkish Language } \\
\text { and Literature }\end{array}$ & Economy & History & $\begin{array}{c}\text { Hospitality } \\
\text { Management }\end{array}$ & Sociology & Total \\
\hline OEQ are more & Disagree & $53.8 \%{ }_{a}$ & $51.7 \%_{a}$ & $82.6 \%{ }_{b}$ & $63.6 \%_{a, c}$ & $77.3 \%_{b, d}$ & $72.7 \%_{c, d}$ & $72.90 \%$ \\
\hline & Agree & $46.2 \%$ & $48.3 \%^{3}$ & $17.4 \%_{b}$ & $36.4 \%_{a, c}$ & $22.7 \%_{b, d}$ & $27.3 \%_{c, d}$ & $27.10 \%$ \\
\hline
\end{tabular}

$X^{2}=102.150 ; d f=5 ; p<0.05$

\begin{tabular}{llccccccc}
\hline & Philosophy & $\begin{array}{c}\text { Turkish Language } \\
\text { and Literature }\end{array}$ & Economy & History & $\begin{array}{c}\text { Hospitality } \\
\text { Management }\end{array}$ & Sociology & Total \\
\hline $\begin{array}{l}\text { OEQ reflect } \\
\begin{array}{l}\text { my knowledge } \\
\text { level }\end{array}\end{array}$ & Disagree & $60.5 \%_{\mathrm{a}, \mathrm{b}}$ & $57.6 \%_{\mathrm{b}}$ & $84.9 \%_{\mathrm{c}}$ & $70.7 \%_{\mathrm{a}, \mathrm{b}}$ & $75.0 \%_{\mathrm{a}, \mathrm{d}}$ & $80.8 \%_{\mathrm{c}, \mathrm{d}}$ & $77.80 \%$ \\
\hline
\end{tabular}

$X^{2}=103.777 ; d f=5 ; p<0.05$

\begin{tabular}{llccccccc}
\hline & Philosophy & $\begin{array}{c}\text { Turkish Language } \\
\text { and Literature }\end{array}$ & Economy & History & $\begin{array}{c}\text { Hospitality } \\
\text { Management }\end{array}$ & Sociology & Total \\
\hline $\begin{array}{l}\text { OEQ were } \\
\text { easier }\end{array}$ & Disagree & $85.8 \%_{\mathrm{a}, \mathrm{b}}$ & $67.8 \%_{c}$ & $93.1 \%_{\mathrm{b}}$ & $88.5 \%_{\mathrm{a}, \mathrm{b}}$ & $86.8 \%_{\mathrm{a}}$ & $91.8 \%_{\mathrm{a}, \mathrm{b}}$ & $89.50 \%$ \\
\hline
\end{tabular}

$X^{2}=113.014 ; d f=5 ; p<0.05$

\begin{tabular}{llccccccc}
\hline & & Philosophy & $\begin{array}{c}\text { Turkish Language } \\
\text { and Literature }\end{array}$ & Economy & History & $\begin{array}{c}\text { Hospitality } \\
\text { Management }\end{array}$ & Sociology & Total \\
\hline \multirow{2}{*}{ EOQ are useful } & Disagree & $61.1 \%_{\mathrm{a}}$ & $61.2 \%_{\mathrm{a}}$ & $89.6 \%_{\mathrm{b}}$ & $72.9 \%_{\mathrm{a}, \mathrm{c}}$ & $84.8 \%_{\mathrm{b}, \mathrm{d}}$ & $80.8 \%_{c, \mathrm{~d}}$ & $80.60 \%$ \\
& Agree & $38.9 \%_{\mathrm{a}}$ & $38.8 \%_{\mathrm{a}}$ & $10.4 \%_{\mathrm{b}}$ & $27.1 \%_{\mathrm{a}, \mathrm{c}}$ & $15.2 \%_{\mathrm{b}, \mathrm{d}}$ & $19.2 \%_{c, \mathrm{~d}}$ & $19.40 \%^{2}$ \\
\hline
\end{tabular}

$X^{2}=129.537 ; d f=5 ; p<0.05$

"Subscripted letters" under the percentages show the gender group that shows significant difference at 05 level of significance.

Table 4 shows that the students disagree with the statements about open-ended questions to a great extent regardless of the programs they attend; however, there are differences between the programs in terms of level of agreement. For instance, Economy students tend to disagree more than those of other programs for the statements "open-ended questions measure important knowledge in the subject matter better, "open-ended questions are fairly graded" and "open-ended questions reflect knowledge level". As for the statement "openended questions were easier than multiple-choice questions", the students attending Turkish Language and Literature program displayed less tendency to disagree with the statements when compared to those attending other programs. In other words, Turkish Language and Literature program student agree with the statement "open-ended questions were easier than multiple-choice questions" more than other participants. Finally, the group that disagreed the most with the statement "I find long answer questions useful in terms of measuring subject matter competence" is the students attending the Economy program. 


\section{DISCUSSION, CONCLUSION AND RECOMMENDATIONS}

This study aims to determine students' opinions about open-ended question exam practice during 20182019 academic year in the following programs of Anadolu University Open Education System: Economy, Hospitality Management, Philosophy, History, Sociology, Turkish Language and Literature. The results of the study are presented below.

First, the participants think that open-ended questions do not measure their subject matter knowledge. Whereas, Javid (2014) stated that the reliability of open-ended questions is higher than multiple-choice questions. The reason lying behind this result of the study might be the prejudices they have about openended questions or that they are not accustomed to this type of question.

The finding related to the evaluation of open-ended questions revealed that almost half of the participants disagree with the statement "open-ended questions are fairly graded", which might be due to the fact that students do not have enough knowledge about this evaluation process. This result supports what has been stated in the literature about open-ended questions. The most obvious drawback was the lack of objectivity and rater bias in the evaluation of open-ended questions (Atilgan, Kan, and Dogan, 2009; Eckes, 2005). Thus, it is recommended that students should be informed about the evaluation process and scoring procedures. Publishing short online videos might be a good solution.

Students do not believe that the points they get from open-ended questions reflect their knowledge level. Therefore, it might be useful to conduct another study to determine the factors leading to this opinion.

Another finding of the study is that students find open-ended questions more difficult than multiple-choice questions. This result is in parallel with another research result (Oksuz\&Guven Demir, 2019; Duran\&Tufan, 2017). The researchers stated that this might be because open-ended items require remembering information and expressing it in written form. The factors affecting this idea might be the lack of options for answers, absence of luck-based success (Turgut\&Baykul, 2012) and that the students are supposed to express their own opinions in their answers in open-ended questions. It may be presupposed that open-ended questions are difficult for learners, and this may have affected students' thoughts.

In long answer questions, students are expected to write at least one paraGraph about the topic. Majority of students think that this question type does not measure their subject matter competencies. Economy students are more negative about this issue. Therefore, further studies might be conducted to identify the reasons lying behind this finding.

Another finding of the study is that majority of students do not prefer that the exams should include only open-ended questions, which is not supported by the findings of the study conducted by Karadag (2014) on alternative measurement tools in Open Education System. Therefore, it might be useful to collect data about students' preferences for measurement tools specific to each program.

When the findings of the study are examined in terms of gender variable, it is seen that more males than females believe that open-ended questions are not fairly graded, and they are not easy and useful. In other words, males have more negative opinions than females about open-ended questions. Another study conclusion supports this finding (Oksuz\&Guven Demir, 2019). It is stated that the female students were more successful in the open-ended test in the analysis step. Du Plessis \&Du Plessis (2009) found that male students who were successful in the multiple-choice test failed in open-ended versions of the same questions.

As for age variable, the participants in 17-22 age group believe that open-ended questions do not measure subject matter content better, are not fairly graded and not useful in measuring competency in subject matter more than students who are 35 year old and over.

According to the findings related to the program they attend, we can see that the students attending Economy program are more negative than students of other programs for the following statements: "I believe that open-ended questions measure important knowledge in the subject matter better; "I believe that open-ended questions are fairly graded"; and "I find long answer questions useful in terms of measuring subject matter competence".

The participants generally believe that the time allocated for the exam involving open-ended questions (30 minutes) for 16 multiple-choice questions and 3 open-ended questions (two short answer and one long 
answer) is sufficient to allow them to answer all the questions. The students who experience problems with the duration of the exam should be examined in a further study. For example, it should be examined whether students face difficulties in time management or difficulty of reading and whether these problems affect their scores or not.

Finally, it was found that majority of students leave open-ended questions blank. The reasons reported for this preference are as follows: they did not know the answer; they could not remember the answer; and they found the question difficult. There are studies in the literature that support this result (Oksuz\&Guven Demir, 2019; Duran\&Tufan, 2017; Eckes, 2005). The most important reason for students to leave openended questions blank might be the $10 \%$ weight of these questions in the overall exam score. An increase in this percentage might change this behavior in a positive way.

\section{BIODATA and CONTACT ADDRESSES of AUTHORS}

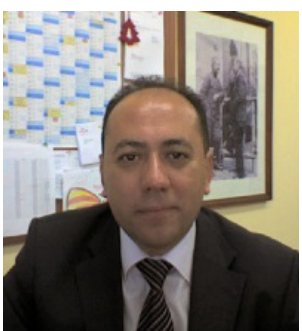

Dr. Nejdet KARADAG, works as the manager of the Assessment Department at the Open Education Faculty of Anadolu University. He has a BA degree from the Department of French Language Teaching and MA degree from the Department of Distance Education. He received his PhD. in Distance Education from Anadolu University in 2014. His research interests are instructional design, assessment and evaluation, mega universities, and new learning technologies in open and distance learning.

\section{Nejdet KARADAG}

Non-Formal Education, Open Education Faculty

Address: Anadolu University, 26470, Eskisehir, Turkey

Phone: +90 2223350580

E-mail: nkaradag@anadolu.edu.tr

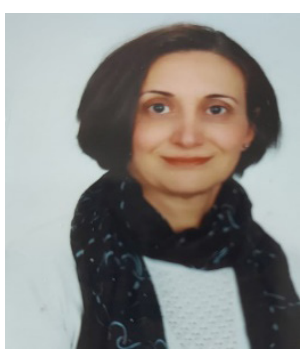

Dr. Belgin BOZ YUKSEKDAG has been working at Anadolu University College of Open Education Testing\&Research Center as a lecturer doctor. She graduated from the School of Nursing of Hacettepe University in 1990. She earned her MS degree from the Graduate School of Istanbul University (Health Sciences Department), Internal Medicine Nursing in 1995, and the MA degree from the Graduate School of Anadolu University (Distance Education Department) in 2008. She earned her $\mathrm{PhD}$ degree from the Graduate School of Marmara University (Health Sciences Department), Psychiatry Nursing, in 2013.

Belgin BOZ YUKSEKDAG

Department Of Health Programs, Open Education Faculty

Address: Anadolu University, 26470, Eskisehir, Turkey

Phone: +90 2223350580

E-mail: bboz@anadolu.edu.tr 


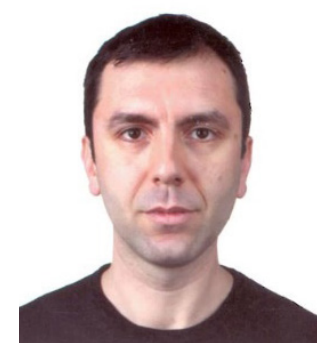

Murat AKYILDIZ

Non-Formal Education, Open Education Faculty

Address: Anadolu University, 26470, Eskisehir, Turkey

Phone: +90 2223350580

E-mail: muratakyildiz@anadolu.edu.tr

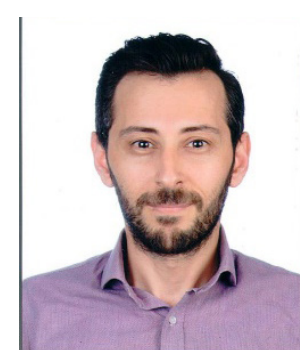

Ali Ihsan IBILEME is a Lecture and Software Developer at Computer Research Center, Anadolu University. He completed his bachelor's degree in Anadolu University, Department of Computer Education and Instructional Technology in 2009. He completed his master's degree, and he is currently a PhD student at the Department of Distance Education, Anadolu University. He take part in the development of many software projects in the field of open and distance learning in Open Faculty, Anadolu University. His academic interest areas are open and distance learning, learning analytics, social network analysis, and learner support system.

Ali Ihsan IBILEME

Anadolu University, Computer Research Center

Address: Anadolu University Computer Research Center, Eskisehir, Turkey

Phone: +90 5544170415,

E-mail: aiibileme@anadolu.edu.tr

\section{REFERENCES}

Atilgan, H., Kan, A., \& Dogan, N. (2009). Egitimde olcme ve degerlendirme. Ani Yayincilik.

Bahar, M., Nartgun, Z., Durmus, S., \& Bicak, B. (2010). Geleneksel-tamamlayici olcme ve degerlendirme teknikleri. Ankara: Pegem Akademi Yayincilik.

Dogan, N. (2013). Yazili yoklamalar. H. Atilgan (Ed.), Egitimde olcme ve degerlendirme icinde (145-168). Ankara: Ani Yayincilik.

Du Plessis, S., \& Du Plessis, S. (2009). A new and direct test of the 'gender bias' in multiple-choice questions.

Duran, E., \& Tufan, B. S. (2017). The Effect Of Open-Ended Questions And Multiple Choice Questions On Comprehension, International Journal of Languages' Education and Teaching, 5(1), 242-254.

Eckes, T. (2005). Examining rater effects in TestDaF writing and speaking performance assessments: A many-facet Rasch analysis. Language Assessment Quarterly: An International Journal, 2(3), $197-$ 221.

Gronlund, N.E. (1998). Assessment of student achievement. Boston: Allyn and Bacon.

Ilhan, M. (2016). Acik uclu sorularla yapilan olcmelerde klasik test kurami ve cok yuzeyli rasch modeline gore hesaplanan yetenek kestirimlerinin karsilastirilmasi. Hacettepe Universitesi Egitim Fakultesi Dergisi [Hacettepe University Journal of Education], 31(2), 346-368. DOI:10.16986/ HUJE.2016015182

Javid, L. (2014). The Comparison between Multiple-choice (MC) and Multiple True-false (MTF) Test Formats in Iranian Intermediate EFL Learners' Vocabulary Learning. Social and Behavioral Sciences 98, 784- 788. doi: 10.1016/j.sbspro.2014.03.482. 
Karadag, N. (2005). Anadolu Universitesi Acikogretim Sisteminde Soru Yazarlarinin Soru Hazirlamada Karsilastiklari Guclukler. The Turkish Online Journal of Educational Technology (TOJET), 4(3).

Karadag, N. (2014). Acik ve Uzaktan Egitimde Olcme ve Degerlendirme: Mega Universitelerdeki Uygulamalar. Yayinlanmamis Doktora Tezi. Anadolu Universitesi Sosyal Bilimler Enstitusu, Eskisehir.

Karadeniz, A. (2016). Kitlesel acik ve uzaktan ogrenmede basarinin acik uclu sorularla olculmesine yonelik bir sistemin tasarimi, uygulanmasi ve degerlendirilmesi. (Design, Evaluation And Implementation of A System Intended to Assess The Learners' Achievement Through Openended Quesions In Massive Open And Distance Learning). Anadolu University, Turkey. Graduate School of Social Sciences, (Doctoral dissertation). Available from the Council of Higher Education, National Dissertation Center, Dissertation ID: 449995.

McIsaac, M.S., \& Gunawardena, C.N. (1996). Distance education. Handbook of research for educational communications and technology (Ed: D. Jonassen). New York: Simon and Schuster Macmillan, ss. 403.

Oksuz, Y., \& Guven Demir, E. (2019). Acik uclu ve coktan secmeli basari testlerinin psikometrik ozellikleri ve ogrenci performansi acisindan karsilastirilmasi. (Comparison of Open Ended Questions and Multiple Choice Tests in terms of Psychometric Features and Student Performance). Hacettepe Universitesi Egitim Fakultesi Dergisi, 34(1), 259-282. doi: 10.16986/HUJE.2018040550

Ozcelik, D.A. (2011). Olcme ve degerlendirme. Ankara: Pegem Akademi Yayincilik.

Puspitasari, K.A. (2010). Student assessment. Policy and Practice in Asian Distance Education (Ed: T. Belawati ve J. Baggaley). New Delhi: SAGE, pp.60-65.

Simonson, M., Smaldino, S., Albright, M., \& Zvacek, S. (2012). Teaching and learning at a distance: Foundations of distance education (3. Baski). New Jersey: Prentice Hall.

Tan, S., \& Erdogan, A. (2004). Ogretimi planlama ve degerlendirme. Ankara: PegemA Yayincilik.

Thorpe, M. (1998). Assessment and third generation distance education. Distance Education, 19(2), 265286.

Turgut, M.F., ve Baykul, Y. (2012). Egitimde olcme ve degerlendirme. Ankara: Pegem Akademi Yayincilik.

Yasar, M. (2014). Egitimde Olcme ve Degerlendirme Dersine Yonelik Tutum Olceginin Gelistirilmesi. Egitim Bilimleri Arastirma Dergisi (EBAD), 4(1).

Zhang, W., Tsui, C., Jedege, O., Ng, F., \& Kowk, L. (2002). A comparison of distance education in selected Asian open universities. 14. Annual Conference of Asian Association of Open Universities Konferansi'nda sunulan bildiri. Manila, Philippines. http://www.ouhk.edu.hk/cridal/gdenet/ Management/Governance/EAM11A.html. 